\title{
The Effect of Tax Planning, Asset of Deferred Tax, Dferred Tax Expense on Profit Management (Case Study of Manufacturing Companies Listed on the Stock Exchange 2013-2017 Period)
}

\section{Srie Nuning Mulatsih, Nela Dharmayanti, and Aisyah Ratnasari}

Universitas Islam SYekh-Yusuf

\section{Abstract}

The purpose of this research is to know the effect of tax planning, deferred tax asset, and deferred tax expense on earnings management of manufacturing companies listed in Indonesia Stock Exchange (IDX) period 2013 to 2017. The sampling technique used in this study is purposive sampling. Data analysis method used in this research

Corresponding Author: Srie Nuning Mulatsih nuningpurwanto@unis.ac.id

Received: 10 February 2019 Accepted: 14 March 2019 Published: 28 March 2019

Publishing services provided by Knowledge E

(c) Srie Nuning Mulatsih et al. This article is distributed under the terms of the Creative Commons Attribution License, which permits unrestricted use and redistribution provided that the original author and source are credited.

Selection and Peer-review under the responsibility of the ICIEBP Conference Committee.

\section{G OPEN ACCESS}

\section{Introduction}

The financial statement is the most important thing in a company. Because the financial statement presents information about the financial position of internal and external parties which include investors, creditors, governments, bankers, management, and other interested parties as a consideration in making an economic decision. The main focus of internal and external parties in the financial statement is the net income earned by the company in a certain period. This can affect external and internal parties in making decisions, one of which is the basis for determining the amount of tax authorities.

The management is required to manage and improve the operational performance of the company to be better in order to be able to compete with other companies. Not only that, according to Nagaradan Suputra (2017) improving the performance of 
good financial management is also very necessary, which means that various policies in financial management must be able to guarantee the sustainability of the company's business and this is shown by the amount of profit achieved by a company. This kind of situation usually encourages managers to conduct deviant behavior in presenting and reporting earnings information which is known as earnings management practices.

In conducting earnings management, the management will be faced with conditions where if the profit is raised it will reflect good company performance, but on the other hand it will also impact the increase in corporate income tax. In the case of tax revenue between the government and corporate taxpayers, in particular they have different perspectives. The government expects an increase in income from income tax, especially the agency, while the business entity minimizes the corporate tax burden, by conducting tax planning. Tax planning refers to the process of minimizing tax burden but does not violate applicable tax regulations.

The difference in recognition of income and expenses between commercial and fiscal causes differences in calculating the amount of income tax. The difference between the Income Tax payable and the tax expense referred to, insofar as it relates to temporary differences, should be recorded and reflected in commercial financial statements, in deferred tax accounts both deferred tax assets and deferred tax liabilities. Assets contained in this company's balance sheet can be used to reduce taxable income so that it can reduce the tax imposed on the company. While deferred tax expense is the opposite of deferred tax assets which can increase income tax. Yulianti (2005) explains that deferred tax expense can be used to make earnings management to avoid losses to the company. This can be done by delaying income and speeding up to save tax, one of which is by engineering deferred tax expenses related to accruals, allowing management to make earnings management.Based on the background described before, the formulation of the research problem is as follows: 1) Does tax planning affect earnings management? 2) Do deferred tax assets affect earnings management? 3) Does the deferred tax burden affect earnings management? 4) Are tax planning, deferred tax assets, and deferred tax expenses simultaneously affecting profit management?

1. Based on the description of the background and formulation of the problem, the objectives in this study are as follows: 1) To find out whether tax planning has an influence on profit management 2) To find out whether deferred tax assets have an influence on earnings management 3) To find out whether the deferred tax burden have influence on earnings management 4) To find out whether tax planning, deferred tax assets, and deferred tax expenses have a simultaneous effect on earnings management. 


\section{Literature Review}

\subsection{Profit management}

Earnings management is a managerial activity to influence financial statements either by manipulating financial data or information selection of accounting methods and procedures that are generally accepted and recognized that aim to obtain company profits (Sulistyanto, 2008: 50). There are two theories that underlie the emergence of earnings management practices, namely: agency theory and positive accounting theory.

\subsection{Tax planning}

Tax planning is one of the functions of tax management that is used to estimate the amount of tax to be paid and things that can be done to avoid taxes (Syanthi, et al; 2013). Lumbantoruan (1996) in Astutik, and Mildawati (2016) explains that there are several ways that taxpayers can do to minimize tax burden, including: 1) Tax shifting is the transfer or transfer of tax burden from tax subjects to parties others. Thus, the person or entity that is taxed is very likely not to bear the tax burden; 2) Capitalization is a reduction in the price of the object of tax equal to the amount of tax that will be paid later by the buyer; 3) Transformation is a way of tax evasion carried out by a company by covering the tax burden imposed on it; 4) Tax evasion is tax avoidance which is done intentionally by taxpayers by violating the applicable tax provisions; 5) Tax avoidance is a taxpayer's attempt to minimize the tax burden by using real alternatives that can be accepted by the tax authorities.

\subsection{Deferred tax}

Deferred tax occurs due to differences between the Financial Accounting Standards (SAK) and the provisions of the Taxation Regulations, in general there is also a difference between income before tax according to bookkeeping and taxable income. Thus, there will also be a difference between tax expense and tax payable (income tax payable) (Zain, 2007: 189).According Astutik, and Mildawati (2016) deferred tax in principle is the impact of future income tax due to temporary differences (time) between accounting and tax treatment and fiscal losses that can still be compensated in the future (tax loss carry forward) that needs to be presented in the financial statements of a certain period. The impact of future income tax that needs to be recognized, calculated, presented 
and disclosed in the financial statements, is included in the financial statements and comprehensive income statements.

\subsection{Deferred tax assets}

The emergence of deferred tax assets is if income before tax (PSP) is smaller than taxable income (PKP), which means that the tax expense (BP) will be smaller than the tax payable (PT). The deferred tax assets can be calculated by multiplying the temporary differences with the prevailing tax rates when the differences are recovered (Zain, 2007: 200). According to Suranggane (2007) "Deferred tax assets occur when accounting income is smaller than fiscal profit due to temporary differences. This resulted in the company being able to postpone the payable tax in the coming period. "

\subsection{Deferred tax expense}

According to Yulianti (2005), deferred tax expense arises from temporary differences between accounting profit and fiscal profit, the difference is due to the preparation of financial statements, accounting standards provide more flexibility for management in determining accounting principles and assumptions than those allowed according to taxation. According to Purba (2009) in Hakim and Praptyo (2015) said the causes of differences in income tax expense with payable income tax can be categorized into two groups: 1) Permanent or permanent differences, this difference occurs because based on taxation legislation, there is some income that is not is an object of tax while according to fiscal income is recognized as income. This difference results in a difference between fiscal profit and commercial profit permanently. 2) Temporary differences or time, this difference occurs because based on the provisions of taxation legislation is income or costs that may be deducted from the previous accounting period or the next accounting period from the current period.

\subsection{The previous researches}

Hakim and Praptyo (2015) conducted research on the effect of deferred tax assets, and deferred tax expense on earnings management in banking companies listed on the IDX. The results of this study are that there is a significant effect between deferred tax assets and deferred tax expense on earnings management. Negara and Saputra (2017) researched on the effect of tax planning and deferred tax expense on earnings 
management in manufacturing companies listed on the Stock Exchange resulted in tax planning having a positive effect on managementprofit, deferred tax expense has a positive effect on the probability of the company to make earnings management.

\subsection{Hypothesis}

\section{Tax Planning On Earnings Management}

Tax planning related to reporting company profits. High profit will also generate a high tax burden. Therefore, the company uses various earnings management techniques to achieve the target. Planning and earnings management are related to each other, because both have the same goal of achieving profit targets by engineering profit numbers in financial statements. Research Dewi, et al (2017) shows that tax planning has an influence on earnings management, the results of this study are in accordance with Astutik and Mildawati (2016) research that tax planning influences earnings management, where the better the company in implementing earnings management tax planning is applied in the company is also getting better. Based on the explanation above, the hypothesis developed is:

H1: Tax planning has a positive effect on earnings management

\section{Deferred Tax Assets On Earnings Management}

With the enactment of SFAS No. 46 which requires managers to recognize and reassess deferred tax assets which can be referred to as the provision of deferred tax asset value, so this regulation can provide freedom for management to determine the accounting policies used in valuing deferred tax assets in financial statements so that they can be used to identify existing whether or not profit engineering (Suranggane, 2007). Based on the results of Fitriany's (2016) study, deferred tax assets have a significant positive effect on earnings management because the greater the deferred tax assets, the greater the profit management activities. The results of this study are in line with the research of Hakim and Praptyo (2015), in which deferred tax assets whose numbers are enlarged by management are motivated by giving bonuses, political burden on the size of the company and minimizing tax payments so as not to harm the company. Based on the explanation above, the hypothesis developed is: $\mathrm{H} 2$ : Deferred tax assets have a positive effect on earnings management.

3. Deferred Tax Expense On Earnings Management According to Negara and Suputra (2017) that deferred tax expense can be used to detect earnings management 
practices by looking at the results of fiscal corrections in the form of negative corrections. Negative correction is a condition where income according to fiscal accounting is smaller than commercial accounting. This is what causes an increase in deferred tax liabilities in the current account balance sheet and the subsequent period is recognized by the company as deferred tax expense in the income statement. In its research, deferred tax expense has a positive influence on the probability of a company doing earnings management. This means that every increase in deferred tax expense then the probability of a company doing earnings management will increase, and vice versa. In the study it was found that there was indeed earnings management in order to avoid reporting losses to companies listed on the Stock Exchange in 2013-2015. The results of the study are also in line with Amanda and Febrianti (2015), and Yulianti (2005). Based on the explanation above, the hypothesis developed is: H3: Deferred tax expense has a positive effect on earnings management.

\section{Research Methods}

\subsection{The determination of samples, types, and data sources}

The sample selection in this study uses purposive sampling method with the following criteria: 1) Manufacturing companies listed on the Stock Exchange up to the updated period (2016), 2) Companies that have audited annual 2017 financial statements, 3) Companies that have not suffered losses the reporting year to be studied, 4) Companies that have complete data needed in the study. There are 19 manufacturing companies that meet predetermined criteria. The type of data used in this study is secondary data (secondary data). Data sources in this study are audited annual financial statements and published on the Indonesia Stock Exchange website.

\subsection{Operational definition and variable measurement}

\subsubsection{Dependent variable (Profit management)}

In measuring earnings management in this study using a discretionary accrual from the Modified Jones Model. Positive discretionary accrual value means that the pattern of earnings management by increasing profits will be given a value of 1 , while negative discretionary accrual means that the pattern of earnings management is lowering the 
profit will be given a value of 0 . The steps to calculate the discretionary accrual (DA) are as follows: Total Accrual (TAC) is calculated by the formula:

\section{TACit $=$ Nlit - CFOit}

The total accrual value (TAC) is estimated by the ordinary least square (OLS) regression equation as follows:

\subsection{Independent Variables}

\section{Tax Planning}

In this study tax planning is measured using the formula of tax retention rate (tax retention rate), which analyzes a measure of tax management effectiveness in the company's financial statements for the current year, the measure referred to in this study is a measure of the effectiveness of tax planning. (Wild et al., 2004 in Astutik and Mildawati, 2016). The tax retention rate formula:

$$
T R R=\frac{\text { Net Income }_{i t}}{\text { Pretax Income (EBITit) }}
$$

Information:

TRRit $=$ Tax Retention Rate (tax retention rate) company $\mathrm{i}$ in year $\mathrm{t}$.

Net Incomeit $=$ net profit of company $\mathrm{i}$ in year $\mathrm{t}$.

Pretax Income = company pre-tax profit year $\mathrm{t}$.

\section{Deferred Tax Assets}

In this study the deferred tax asset variable is measured by the change in the value of deferred tax assets at the end of period $t$ with $t-1$ divided by the value of deferred tax assets at the end of period $t$.

$$
\text { DTAit }=\frac{\Delta{\text { Deferred Tax } \text { Assets }_{i t}}_{\text {Asset Of Deferred Tax }}}{\text { As }}
$$

\section{Deferred tax expenses}

Deferred tax expense which is used as a variable in this study is derived from deferred tax expense in the financial statements divided by total assets in the previous period. The deferred tax expense calculation is calculated using indicators weighing deferred tax expense with total assets. This is done to weight the deferred tax burden with total assets in period t-1 to obtain proportionally calculated value. (Fitriany, 2016).

$$
\text { DTEit }=\frac{\text { Deffered Tax Expenses }_{i t}}{\text { Total Asset }_{t-1}}
$$




\section{Data analysis method}

The method that will be used to analyze data and test hypotheses is by using descriptive statistics and testing hypotheses using logistic regression using the help of Microsoft Excel 2013 software and SPSS Version 25.0.

\section{Conclusions}

The population in this study are manufacturing companies listed on the Indonesia Stock Exchange (IDX) during the 2013-2017 period. The sampling technique in this study uses purposive sampling with predetermined criteria. The results of sample analysis using purposive sampling are shown in Table 1.

TABLE 1: Criteria For Sampling.

\begin{tabular}{l|l|c|} 
No. & Description & Amount \\
\hline 1 & $\begin{array}{l}\text { Manufacturing company listed on } \\
\text { the IDX until } 2016 \text { period }\end{array}$ & 144 \\
\hline 2 & $\begin{array}{l}\text { Companies that have not uploaded } \\
\text { the } 2017 \text { audited annual financial } \\
\text { statement }\end{array}$ & 21 \\
\hline 3 & $\begin{array}{l}\text { Companies that do not use IDR } \\
\text { (Indonesian Rupiah) fund }\end{array}$ & 22 \\
\hline 4 & $\begin{array}{l}\text { Companies that experience losses } \\
\text { during the period that will be } \\
\text { examined }\end{array}$ & 27 \\
\hline 5 & $\begin{array}{l}\text { Companies that do not have } \\
\text { complete data }\end{array}$ \\
\hline Result/sample & 55 \\
\hline Source:www.sahamok.com and reprocessed, 2018 \\
\hline
\end{tabular}

\subsection{Data analysis and discussion}

\section{Statistic Descriptive Analysis}

This analysis is done to get an overview of all variables. Descriptive statistics are presented in Table 2. And Table 3 shows the frequency for nominal scale variables

2. The descriptive test results on Table 2 show that the activity of gain (EM) has an average value (mean) of 0.6421 and a standard standard of 0.48192 . Table 3 shows the frequency of activity in the management of 34 companies or $35.8 \%$ of the sample did a decline in the age of 61 companies or $64.2 \%$ to increase profits. 
TABLE 2: Descriptive Statistics Test Results (Source:Output SPSS 25).

\begin{tabular}{|c|c|c|c|c|c|}
\hline & $\mathrm{N}$ & Min & $\operatorname{Max}$ & Mean & $\begin{array}{c}\text { Std } \\
\text { Deriation }\end{array}$ \\
\hline EM & 95 & 0 & 1.0 & 6421 & 48192 \\
\hline TPL & 95 & 419129 & 995923 & 731226 & .089543 \\
\hline DTA & 95 & 5,579004 & 979491 & 087936 &, 719834 \\
\hline DTE & 95 & 000000 & 082932 & 013173 & .018653 \\
\hline $\begin{array}{l}\text { Valis N } \\
\text { (listwise) }\end{array}$ & 95 & & & & \\
\hline
\end{tabular}

TABLE 3: Frequency Table Earning Management (Source:Output SPSS 25).

\begin{tabular}{|c|c|c|c|c|c|}
\hline & & $\begin{array}{c}\text { Frequenc } \\
y\end{array}$ & $\begin{array}{l}\text { Perce } \\
\text { et }\end{array}$ & $\begin{array}{r}\text { Valid } \\
\text { Percent }\end{array}$ & $\begin{array}{l}\text { Cumulative } \\
\text { Pescent }\end{array}$ \\
\hline \multirow{3}{*}{ Vali } &, 00 & 34 & 35,8 & 35,8 & 35,8 \\
\hline & $\infty^{1,}$ & 61 & 642 & 64,2 & 100,0 \\
\hline & $\begin{array}{l}\text { To } \\
\mathrm{eal}\end{array}$ & 95 & 100,0 & 100,0 & \\
\hline
\end{tabular}

This means that the number of manufacturing companies in the period of 2013 to 2017 tends to be more that carry out the management activities of the city by increasing their prices. Activity planning (TPL) has an average value (mean) of 0.731226 and a standard standard of 0.089543 , the minimum value of tax planning is 0.419129 and the maximum value is 0.998923. Deferred tax assets (DTA) have an average (mean) value of 0.087936 and a national standard of 0.719834 with the lowest number of -5.579004 and the highest is 0.979491. Deferred expenses (DTE) have an average value (mean) of 0.013173 and a standard standard of 0.018653 with a minimum value of 0.000000 and a maximum of 0.082932 .

\section{Classic assumption test}

\subsection{Multicolinearity test}

The analysis technique in this study does not require the assumption of normality, heteroskedacity, and classical assumptions on the independent variables. Because the classic assumption test is aimed at the method of analysis using the estimation method of ordinary least square (OLS) only (Setiawan, 2013). However, Negara and Suputra (2017) in their research conducted a multicollinearity test for this logistic regression analysis technique. Multicollinearity test results for independent variables namely tax planning 
(TPL), deferred tax assets (DTA), and deferred tax expense (DTE) are described in Table 4 below:

TABLE 4: Multicollinearity Test Result (Source: Output SPSS 25).

\begin{tabular}{|c|c|c|c|c|c|c|c|c|}
\hline \multirow{2}{*}{\multicolumn{2}{|c|}{ Moth! }} & \multicolumn{2}{|c|}{ 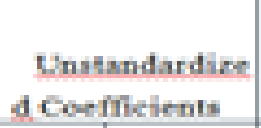 } & \multirow{2}{*}{ 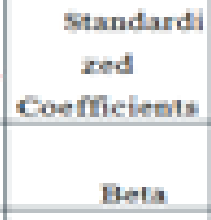 } & \multirow[b]{2}{*}{$T$} & \multirow[b]{2}{*}{$\mathrm{g}^{5}$} & \multirow{2}{*}{ 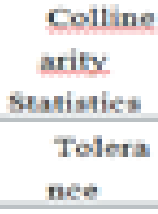 } & \multirow{2}{*}{ 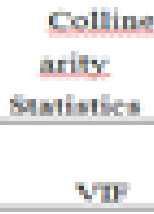 } \\
\hline & & H & $\begin{array}{c}\text { Esed. } \\
\text { Error }\end{array}$ & & & & & \\
\hline \multirow[t]{4}{*}{1} & Consi & $1=$ & 110 & & 1846 & & & \\
\hline & TPL & 14 & 145 & 200 & $\begin{array}{l}2.3 \\
43\end{array}$ & $\operatorname{sog}$ & sop & $1 \pm 13$ \\
\hline & DTA & 62k & 817 & $-17 s$ & 1050 & 913 & 913 & 1005 \\
\hline & DTI: & $\begin{array}{r}71 \\
2\end{array}$ & $\operatorname{stc}$ & 050 & 4 & siog & \$TP & 1.117 \\
\hline
\end{tabular}

From the results of multicollinearity, it is described in Table 4.9 where there is no independent variable that has a less Tolerance value than 0.10 which means that the independent variable correlations are not independent. Results on Variance Inflation CalculationsThe factor (VIF) also shows the same thing that is not an independent variable that has a VIF value of more than 10 . So, it can be concluded that there is no difference in the value of polyolearity between independent variables in the regression model.

\subsection{Test the feasibility of regression models}

Testing the overall model fit is done by comparing the values between -2 Log Likelihood $(-2 L L)$ at the beginning (Block Number $=0$ ) with the final -2 Log Likelihood $(-2 L L)$ (Block Number $=1$ ). If -2 Log Likelihood $(-2 L L)$ at the beginning (Block Number $=0$ ) is greater than -2 Log Likelihood $(-2 L L)$ end (Block Number $=1$ ) then it can be concluded that the model hypothesized is fit with data, and vice versa.

TABLE 5: Overall Model Fit.

\begin{tabular}{lc}
\multicolumn{3}{c}{ Overall model fit(-2LogL) } \\
\hline -2LogL Block Number $=0$ & 123,917 \\
-2 LogL Block Number $=1$ & 116,584 \\
Source: Output SPSS 25 &
\end{tabular}

From table 5 shows the initial -LogL value (-2LogL Block Number $=0$ ), where the model only enters constants, shows the value of 123.917 while the value of -2 LogL in the next 
step (-2LogL Block Number = 1), where this model is included constant and independent variable shows a smaller value which is 116.584. Comparison of the different values can be seen when the value of -2 LogL Block Number $=0$ is more than the value of -2 LogL Block Number $=$ with a decrease of 7.333 so that it can be concluded that the model hypothesized is compatible with the data.

\subsection{Hosmer and Lemeshow's goodness of fit test}

The feasibility of this regression model is assessed using Hosmer and Lemeshow by observing the value of goodness of fit as measured by the Chi-Square value. If a significant probability is greater than $0.05, \mathrm{HO}$ is accepted and means the model can be used because there is no significant difference between the classifications predicted by the observed classification.

TABLE 6: Hosmer and Lemeshow Test.

\begin{tabular}{|c|c|c|c|}
\hline Step & Chi-square & Df & Sig. \\
\hline \begin{tabular}{l|c|} 
1 \\
6,399
\end{tabular} & 8 &, 603 \\
\hline
\end{tabular}

The test results in Table 6 show the Chi-Square value of 6.399 with a significant value of 0.603 . From these results it can be seen that the significant value $>\alpha=0.05$ (significant above 0.05) which means that $\mathrm{HO}$ is accepted. This shows that the model is able to predict the value of its observations or the model can be accepted because it matches the observational data so that this model can be used for further analysis.

\subsection{Determination coefficient (Nagelkerke's R square)}

Nagelkerke's R Squared value varies between 1 (one) and 0 (zero). The more detectable the value is 1 , the model is considered to be goodness of fit while getting closer to 0 , the model is not good of fit.

TABLE 7: Model Summary.

\begin{tabular}{|c|c|c|c|}
\hline Step & $\begin{array}{l}-2 \text { Log } \\
\text { likelihood }\end{array}$ & $\begin{array}{c}\text { Cox \& Snell } \\
\text { R Square }\end{array}$ & $\begin{array}{c}\text { Nagelkerke } \\
\text { R Square }\end{array}$ \\
\hline 1 & $116,584^{a}$ & ,074 & 102 \\
\hline
\end{tabular}

From Table 7 the value of Nagelkerke R Square is 0.102 , and the value of Cox \& Snell $\mathrm{R}$ Square is 0.074 . This shows that the ability of the independent variable is tax 
planning, deferred tax assets, deferred tax burden can explain the dependent variable that is earnings management of $10.2 \%$, the remaining $89.8 \%$ is influenced by other factors outside the variables used in the study.

\subsection{Hypothesis testing simultaneous testing (F / Chi Square Omnibus Test Test of Model Coefficients)}

Tests of simultaneous using Table Omnibus Tests of Model Coefficients using gravity test with an enter method of significance level $(\alpha)$ of $5 \%$.

TABLE 8: Omnibus Test of Model Coefficients.

\begin{tabular}{|c|c|c|c|c|}
\hline & & Chi-square & df & Sig. \\
\hline \multirow[t]{3}{*}{ Step 1} & Step & 7,333 & 3 & ,062 \\
\hline & Block & 7,333 & 3 & ,062 \\
\hline & Model & 7,333 & 3 & ,062 \\
\hline
\end{tabular}

From the results of logistic regression testing in Table 8 Omnibus Tests of Model Coefficients, it is known that the chi-square value $=7.333$ with degree of freedom $=3$ and a significance level of 0.062 ( $p$-value $>0.05$ ). This shows that planning tax, deactivated assets, and the burden of insurance are not in harmony with the management of earnings.

\section{Partial Testing (T / Wald Statistics Statistics Test) Testing uses logis- tical analysis with Wald}

Statistic. Acceptance or rejection of $\mathrm{HO}$ is influenced by significance level $(\alpha)$ TABLE 9: Summary Of Logistic Regression Test Result (Source: Output SPSS V.25).

\begin{tabular}{|c|c|c|c|c|c|}
\hline & & B & Wald & Sigt & Informstion \\
\hline \multirow[t]{4}{*}{ It } & TPL & $\begin{array}{r}705 \\
6\end{array}$ & 5,329 & $\phi 21$ & Signiflesut \\
\hline & DTA & & 1,382 & 240 & Not Signifiesnt \\
\hline & DTE & $\begin{array}{r}111 \\
4\end{array}$ & 008 & $\$ 31$ & Not Significant \\
\hline & Constue & 4313 & 3,905 & 048 & \\
\hline
\end{tabular}


From the results of the regression logic tests on Table 9, it is obtained that the equation of the regression model is as follows: Ln EM / (1-EM) $=-4,513+7,056$ TPL$0,484 \mathrm{DTA}+1,114$ DTE $+\varepsilon$

From the logistic regression equation above it can be seen that the value of the constant of -4.513 indicates that when all Xbernilate variables remain, the $Y$ variable has probability decreases to 4.513 . The regression coefficient $\beta 1$ of 7.056 shows that when the planning of the value of 1 is temporary while the duty rate is deactivated, and the number of time-loss policies is fixed, the number of variables for management of the library has a probability increase of 7.056. The regression coefficient of $\beta 2$ of -0.448 shows that if the response time value is 1 while the tax plan and the number of time frames are fixed, the number of variables in the management plan has a probability of decreasing by 0.484 . The regression coefficient of $\beta 3$ of 1.114 shows that the package of the number of times the value of 1 set of tax planning in the fixed period exposure is fixed, the number of variables for management in terms of probability increases by 1.114 .

\section{Discussion of Research Results}

Based on the results of the study, tax planning variables, deferred tax assets and deferred tax expenses do not simultaneously affect earnings management in manufacturing companies listed on the IDX for the 2013-2017 reporting period. However, tax planning as measured by tax retention rate has a positive influence on earnings management, this means that $\mathrm{H} 1$ is accepted. The results of this study support the research of Fitriany (2016) and Negara and Suputra (2017), this is because the company does not want to be taxed too much so that the company does earnings management with tax planning activities so the tax will be smaller. Deferred tax assets and deferred tax expense have no significant effect on earnings management, this means that $\mathrm{H} 2$ and $\mathrm{H} 3$ are rejected. The results of this study are in accordance with research conducted by Suranggane (2007), Onasisand Aquino (2016), and Amanda and Febrianti (2015). According to Suranggane (2007) there are several reasons that can be used as a reason why companies do not utilize deferred tax assets to engineer profits, one of which is the close link between deferred tax assets and taxation provisions. That is, if a manager makes use of deferred tax assets on commercial financial statements to make earnings management, this can affect his fiscal financial statements because deferred tax assets reported on commercial finance in the long run must match the fiscal financial statements. So, it will make managers have to "play their brain" so that the 
amount of deferred tax assets that are engineered does not cause large tax payments and will harm the company. Based on the discussion of the results of this study, the following conclusions can be drawn: 1) Tax planning, deferred tax assets and deferred tax expenses do not affect simultaneously earnings management; 2) Tax planning has a significant positive effect on earnings management; 3) Deferred tax assets do not significantly affect earnings management; 4) Deferred tax expense does not significantly affect earnings management. Based on the above conclusions, the advice that can be given is that for further research it is recommended to use other calculations to detect earnings management activities. For example scaled earnings changes, Modes Jones, etc.; It is also recommended to add or replace some independent variables that are thought to have a greater influence on earnings management; and it is recommended to add or change the sample, add to the observation period to be examined or enter a sample of companies that not only experience profits.

\section{References}

[1] Aditama, Ferry., dan Anna Purwaningsih. 2014. Pengaruh Perencanaan Pajak Terhadap Manajemen Laba pada Perusahaan Nonmanufaktur yang Terdaftar di Bursa Efek Indonesia. Modus. Vol. 26

[2] Amanda, Felicia., dan Meiriska Febrianti. 2015. Analisis Pengaruh Beban Pajak Kini, Beban Pajak Tangguhan, dan Basis Akrual Terhadap Manajemen Laba. Ultima Accounting. Vol. 7

[3] Astutik, Ratna Eka Puji., dan Titik Mildawati. 2016. Pengaruh Perencanaan Pajak dan Beban Pajak Tangguhan Terhadap Manajemen Laba. Jurnal IImu dan Riset Akuntansi. Vol. 5

[4] Dewi, Rafika Eva, Elva Nuraina dan Nik Amah. 2017. Pengaruh Tax Planning dan Ukuran Perusahaan Terhadap Manajemen Laba. Forum IImiah Pendidikan Akuntansi. Vol. 5

[5] Fitriany, Lucy Citra. 2016. Pengaruh Aset Pajak Tangguhan, Beban Pajak Tangguhan, dan Perencanaan Pajak Terhadap Manajemen Laba. JOM Fekon. Vol. 3

[6] Ghozali, Imam. 2016. Aplikasi Analisis Multivariate dengan Program IBM SPSS 23 Edisi 8. Semarang: Badan Penerbit Universitas Diponegoro.

[7] Hidayat, Anwar. 2015. Regresi Logistik. https://www.statistikian.com/2015/02/ regresi-logistik.html. Diakses 09 April 2018.

[8] Indonesia Stok Exchange. http://www.idx.co.id/id-id/beranda/perusahaantercatat/ laporankeuangandantahunan.aspx. Diakses 10 April 2018. 
[9] Latuamury, Jabida, Nur Fadjrih Asyik, Nur Handayani. 2013. Pengaruh Book Tax Differences dan Cash Flow Operation Terhadap Perilaku Manajemen Laba dan Persistensi Laba. Jurnal IImu dan Riset Akuntansi. Vol. 2

[10] Negara, A.A Gede Raka Plasa., I.D.G. Dharma Suputra. 2017. Pengaruh Perencanaan Pajak dan Beban Pajak Tangguhan Terhadap Manajemen Laba. E-Jurnal Akuntansi Universitas Udayana. Vol. 20

[11] Onasis, Dini., dan Afvan Aquino. 2016. Pengaruh Aktiva Pajak Tangguhan Terhadap Manajemen Laba Perusahaan Industri Manufaktur Basic Industri yang Terdaftar di Bursa Efek Indonesia. Jurnal Daya Saing.

[12] Pohan, Chairil Anwar. 2015. Manajemen Perpajakan Strategi Perencanaan Pajak dan Bisnis Edisi Revisi. Jakarta: PT. Gramedia Pustaka Utama.

[13] Saham Ok. http://www.sahamok.com/perusahaan-manufaktur-di-bei/manufaktur2016/. Diakses 8 April 2018.

[14] Singkianti, Inasa. 2015. Skripsi Pengaruh Aset Pajak Tangguhan, Beban Pajak Tangguhan dan Perencanaan Pajak Terhadap Manajemen Laba. Fakultas Ekonomi dan Bisnis. Universitas Muhammadiyah Surakarta. Surakarta.

[15] Suandy, Erly. 2016. Perencanaan Pajak Edisi 6. Jakarta: Salemba Empat.

[16] Sulistyanto, Sri. 2008. Manajemen Laba Teori dan Model Empiris. Jakarta: PT. Gramedia Widiasarana Indonesia.

[17] Suranggane, Zulaikha. 2007. Analisis Aktiva Pajak Tangguhan dan Akrual Sebagai Prediktor Manajemen Laba. Jurnal Akuntansi dan Keuangan Indonesia. Vol. 4

[18] Syanthi, Nila Trisna, Made Sudarma dan Erwin Saraswati. 2013. Dampak Manajemen Laba Terhadap Perencanaan Pajak dan Persistensi Laba. Jurnal Ekonomi dan Keuangan. Vol. 17, No. 2

[19] Yulianti. 2005. Kemampuan Beban Pajak Tangguhan dalam Mendeteksi Manajemen Laba. Jurnal Akuntansi dan Keuangan Indonesia. Vol.2

[20] Zain, Mohammad. 2007. Manajemen Perpajakan Edisi 3. Jakarta: Salemba Empat 